\title{
Potential of Melia dubia agroforestry system in soil improvement and environmental sustainability
}

\author{
Narender ${ }^{1}$, Arya, S. $^{2}$ 凶, Nanda, K. ${ }^{3}$
}

\begin{abstract}
The current study intended to understand the influence of Melia dubia based agroforestry system on soil properties. The research was carried out at Gillan Khera in district Fatehabad, situated in the semi-arid region of Haryana. Analysis of soil samples were done for $\mathrm{pH}$, electrical conductivity (EC), organic carbon, soil moisture and available nitrogen, phosphorus and potassium. The soil $\mathrm{pH}$ and $\mathrm{EC}$ decreased more under trees than under control (sole wheat crop) i.e, 8.09 to 7.89 and 0.46 to $0.44 \mathrm{dSm}^{-1}$ respectively. However, the amount of $\mathrm{N}, \mathrm{P}, \mathrm{K}$, organic carbon $(131.38,16.00,301.10(\mathrm{~kg} / \mathrm{ha})$ and $0.46 \%$ respectively) and soil moisture content was found higher in intercropped conditions at both soil depths. Extra moisture in shaded conditions resulting in the breakdown of litter, mineralization and nitrogen gain at a faster rate compared to full sunlight conditions justifies the increased amount of nutrients, organic carbon and other favorable changes in the soil under trees. The current study recommends Melia dubia based agroforestry system as an excellent opportunity in order to enhance soil fertility and for environmental sustainability.
\end{abstract}

Key words: Agroforestry system, Environment, Melia dubia tree, Organic carbon, Soil parameters

\section{Introduction}

Agroforestry is a feasible choice to face environmental challenges and accomplish the demands of fast-growing human population in a sustainable mode. Sustainability necessitates fertile soils and that can be well preserved and enhanced through agroforestry interventions. Trees on agricultural lands are capable of solving a number of complications of agricultural systems for example sustainable biological production, indiscriminate deforestation, declining soil fertility, occurring of droughts and increasing use of dangerous chemicals (Arya et al., 2018). Trees in agroforestry systems improve soil organic matter, $\mathrm{N}$-retention, water holding capacity and infiltration rates in the soil. They help in the preservation of soil fertility through nitrogen fixation and return of organic content through leaf fall (Rosenstock et al., 2014).Soil is the biosphere's greatest reservoir of terrestrial organic carbon; it contains more carbon than the atmosphere in combination with the plants (Magar et al., 2020). The presence of agricultural systems optimizes recycling of nutrients which results in tree species having a positive effect on various soil properties. Agro-forestry technologies

\section{Author's Address}

Department of Forestry, CCSHAU, Hisar 125 004, India.

E-mail.: sandeeparya@hau.ac.in have proved their worth as substitutes (or complements) to fertilizer (Bhardwaj et al., 2020). For decades, studies relating to the interaction between trees, crop and soil have been an interesting subject for researchers. Trees alter soil properties in a variety of ways. Root systems of trees and crops play an important role, since they decide major soil functions via involvement in major below-ground processes (Sto"cker et al., 2020). Proper understanding of interactions of agroforestry and soil processes may aid us in meeting our sustainability goals such as sequestration of soil organic carbon. Soil organic carbon content is often found higher in agroforestry systems compared to treeless croplands, owing to tree litter fall and pruning residues, as well as tree root inputs. Other than inputs of tree canopy by leaf fall there are numbers of ways trees can enhance nutrients through small efforts such as faecal inputs of birds and browsing or grazing animals residing on the tree or near them. Faunal diversity and abundance are habitually found to have a positive effect though, comparing to the forest lands the effects are neutral or negative (Cardinael et al., 2020). The chief benefit of agroforestry is sustainability most researchers focus primarily on the ecological benefits, whereas growers are 


\section{Narender et al.}

concerned only with instantaneous profits and income. As a result, the future must resolve the balance between climate and economy. (Liu et al.,2019). Over the last half-century, a lot of scientific research has shown that a huge number of issues related to sustainability can be tackled through agroforestry that the world is facing (Kmoch et al., 2018, Jemal et al., 2018).

\section{Materials and Methods}

Present soil-tree interaction study estimates modifications in soil fertility and moisture content in a four years old plantation of Melia dubia having wheat varieties grown in interspaces of trees in semi-arid belt of north-western India. The study was carried out at a farmer field at village Gillan Khera in district Fatehabad, situated in the semiarid region of Haryana.The coordinates of the study site were $29^{\circ} 50^{\prime}$ and $75^{\circ} 30^{\prime}$ and altitude $212 \mathrm{~m}$ above mean sea level. Regional climate of the location is subtropical-monsoonic. This place receives $360-400 \mathrm{~mm}$ of average rainfall annually. Maximum temperature (mean) in May and June during summer months ranges from 40 to $45^{\circ} \mathrm{C}$ and minimum temperature of $0^{\circ} \mathrm{C}$ in December and January. The standard package of practices as recommended by CCS Haryana Agricultural University was followed for the cultivation of crops. Collection of soil samples was performed at different depths i.e. $(0-15 \mathrm{~cm}, 15-30 \mathrm{~cm}, 15-45 \mathrm{~cm})$ from the experimental field in three replicates. This was done twice i.e. prior to sowing and later after harvesting of wheat crop. Soil samples were analyzed for electrical conductivity, $\mathrm{pH}$ and organic carbon and nutrients (nitrogen, phosphorus and potassium). First air-drying of soil samples was done and then ground in a wooden pestle and mortar, the ground soil was passed from a stainless steel sieve of $2 \mathrm{~mm}$. The soil obtained was kept to carry out the analysis. The soil $\mathrm{pH}$ and electrical conductivity were determined through distilled water suspension (1:2). Soil samples for soil moisture readings were taken at $0.5 \mathrm{~m}, 1 \mathrm{~m}$, and $1.5 \mathrm{~m}$ distance away from the tree line. Samples were taken three times i.e. before irrigation and the $7^{\text {th }}$ and $14^{\text {th }}$ day after irrigation. The data recorded during the research were analyzed statistically by the Panse and Sukhatme method given in 1985. Soil parameters were estimated following standard procedures (Table1).

Table 1: Standard procedure followed for soil estimation

\begin{tabular}{|l|l|}
\hline Properties & Method \\
\hline $\begin{array}{l}\text { Electrical } \\
\text { conductivity }\left(\mathrm{dS} \mathrm{m}^{-1}\right)\end{array}$ & $\begin{array}{l}\text { Conductivity meter (Jackson, } \\
1973)\end{array}$ \\
\hline Soil $(\mathrm{pH})$ & $\begin{array}{l}\text { Glass electrode pH meter } \\
\text { (Jackson, 1973) }\end{array}$ \\
\hline Organic carbon (\%) & $\begin{array}{l}\text { Partial oxidation method } \\
\text { (Walkley and Black, 1934) }\end{array}$ \\
\hline $\begin{array}{l}\text { Available nitrogen } \\
\left(\mathrm{kg} \mathrm{ha}^{-1}\right)\end{array}$ & $\begin{array}{l}\text { Alkaline permanganate } \\
\text { distillation method } \\
\text { (Subbiah and Asija, 1956) }\end{array}$ \\
\hline $\begin{array}{l}\text { Available phosphorus } \\
\left(\mathrm{kg} \mathrm{ha}^{-1}\right)\end{array}$ & $\begin{array}{l}\text { Sodium bicarbonate method } \\
\text { (Olsen et al., 1954) }\end{array}$ \\
\hline $\begin{array}{l}\text { Available potassium } \\
\left(\mathrm{kg} \mathrm{ha}^{-1}\right)\end{array}$ & $\begin{array}{l}\text { Neutral normal ammonium } \\
\text { acetate method (Jackson, } \\
\text { 1973). }\end{array}$ \\
\hline
\end{tabular}

\section{Results and Discussion}

A significant improvement in the $\mathrm{EC}, \mathrm{pH}$, organic carbon content and various soil nutrients such as available nitrogen, phosphorus and potassium were observed in the soil under tree condition over sole crop (control). The decrease in values of soil $\mathrm{pH}$ was observed under trees as well as in without tree conditions after harvest at $0-15 \mathrm{~cm}$ (Table 2). The results revealed that the maximum decrease in soil $\mathrm{pH}$ was observed under trees at $0-15 \mathrm{~cm}$ soil depths i.e. 8.09 to 7.89 , before sowing to after harvest respectively. There is less change in soil $\mathrm{pH}$ in condition without tree i.e. 7.91 to 7.89 before sowing to after harvest respectively. Compared to the 15-30 cm depth of soil a higher decrease in $\mathrm{pH}$ was found at $0-15 \mathrm{~cm}$ soil depth. There was a slight decrease in soil $\mathrm{pH}$ under Melia dubia after harvest of crop however, negligible change was observed in system without trees from November 2018 to April 2019. The decrease in soil $\mathrm{pH}$ was more under Melia plantation than in control (sole crop). This may be due to microclimate created by crop and tree root system and the acidic nature of litter fall which decreased the soil $\mathrm{pH}$ after decomposition. Similar outcomes were witnessed by Tripathi et al. (2009). Litter decomposition owing to release of organic matter and weak organic acids into the soil is probably the reason for slightly lesser $\mathrm{pH}$ in agrisilviculture systems (Prasadini and Sreemannarayana, 2007). 
Potential of Melia dubia agroforestry system in soil improvement

Table 2: Soil pH and organic carbon content at different depth before sowing and after harvesting of wheat varieties in control (field without trees) and under tree condition

\begin{tabular}{|c|c|c|c|c|c|c|c|c|c|c|c|c|}
\hline \multirow{3}{*}{ Soil Depth (cm) } & \multicolumn{6}{|c|}{ Soil pH } & \multicolumn{6}{|c|}{ Organic carbon $(\%)$} \\
\hline & \multicolumn{3}{|c|}{ Before sowing } & \multicolumn{3}{|c|}{ After harvest } & \multicolumn{3}{|c|}{ Before sowing } & \multicolumn{3}{|c|}{ After harvest } \\
\hline & $\begin{array}{c}\text { Under } \\
\text { Tree }\end{array}$ & $\begin{array}{l}\text { Without } \\
\text { Tree }\end{array}$ & Mean & $\begin{array}{c}\text { Under } \\
\text { Tree }\end{array}$ & $\begin{array}{l}\text { Without } \\
\text { Tree }\end{array}$ & Mean & $\begin{array}{c}\text { Under } \\
\text { Tree }\end{array}$ & $\begin{array}{l}\text { Without } \\
\text { Tree }\end{array}$ & Mean & $\begin{array}{c}\text { Under } \\
\text { Tree }\end{array}$ & $\begin{array}{l}\text { Without } \\
\text { Tree }\end{array}$ & Mean \\
\hline $0-15$ & 8.09 & 7.91 & 8.00 & 7.89 & 7.89 & 7.89 & 0.44 & 0.35 & 0.40 & 0.46 & 0.34 & 0.40 \\
\hline $15-30$ & 8.29 & 7.89 & 8.09 & 8.28 & 7.89 & 8.09 & 0.28 & 0.23 & 0.26 & 0.30 & 0.21 & 0.26 \\
\hline Mean & 8.19 & 7.90 & & 8.08 & 7.89 & & 0.36 & 0.29 & & 0.38 & 0.28 & \\
\hline \multicolumn{13}{|l|}{ C. D. at $5 \%$} \\
\hline Depth & & \multicolumn{2}{|c|}{ NS } & \multicolumn{3}{|c|}{0.08} & \multicolumn{3}{|c|}{0.005} & \multicolumn{3}{|c|}{0.010} \\
\hline Environment & & \multicolumn{2}{|c|}{0.16} & \multicolumn{3}{|c|}{0.08} & \multicolumn{3}{|c|}{0.005} & \multicolumn{3}{|c|}{0.010} \\
\hline $\mathrm{D} \times \mathrm{E}$ & & \multicolumn{2}{|c|}{ NS } & \multicolumn{3}{|c|}{0.12} & \multicolumn{3}{|c|}{0.007} & \multicolumn{3}{|c|}{0.014} \\
\hline
\end{tabular}

Table 3: Soil EC and nitrogen content at different depth before sowing and after harvesting of wheat varieties in control (field without trees) and under tree condition

\begin{tabular}{|c|c|c|c|c|c|c|c|c|c|c|c|c|}
\hline \multirow{3}{*}{ Soil Depth (cm) } & \multicolumn{6}{|c|}{ Soil EC } & \multicolumn{6}{|c|}{ Available nitrogen (kg/ha) } \\
\hline & \multicolumn{3}{|c|}{ Before sowing } & \multicolumn{3}{|c|}{ After harvest } & \multicolumn{3}{|c|}{ Before sowing } & \multicolumn{3}{|c|}{ After harvest } \\
\hline & $\begin{array}{l}\text { Under } \\
\text { Tree }\end{array}$ & $\begin{array}{l}\text { Without } \\
\text { Tree }\end{array}$ & Mean & $\begin{array}{l}\text { Under } \\
\text { Tree }\end{array}$ & $\begin{array}{l}\text { Without } \\
\text { Tree }\end{array}$ & Mean & $\begin{array}{l}\text { Under } \\
\text { Tree }\end{array}$ & $\begin{array}{l}\text { Without } \\
\text { Tree }\end{array}$ & Mean & $\begin{array}{l}\text { Under } \\
\text { Tree }\end{array}$ & $\begin{array}{l}\text { Without } \\
\text { Tree }\end{array}$ & Mean \\
\hline $0-15$ & 0.46 & 0.51 & 0.49 & 0.44 & 0.50 & 0.47 & 130.43 & 109.80 & 120.11 & 131.38 & 108.93 & 120.15 \\
\hline $15-30$ & 0.38 & 0.45 & 0.42 & 0.36 & 0.43 & 0.40 & 126.88 & 107.98 & 117.43 & 127.25 & 107.00 & 117.13 \\
\hline Mean & 0.42 & 0.48 & & 0.40 & 0.47 & & 128.65 & 108.89 & & 129.31 & 107.96 & \\
\hline \multicolumn{13}{|l|}{ C. D. at $5 \%$} \\
\hline Depth & \multicolumn{3}{|l|}{0.007} & \multicolumn{3}{|l|}{0.005} & \multicolumn{3}{|l|}{1.27} & \multicolumn{3}{|l|}{1.31} \\
\hline Environment & \multicolumn{3}{|l|}{0.007} & \multicolumn{3}{|l|}{0.005} & \multicolumn{3}{|l|}{1.27} & \multicolumn{3}{|l|}{1.31} \\
\hline $\mathbf{D} \times \mathbf{E}$ & \multicolumn{3}{|l|}{0.009} & \multicolumn{3}{|l|}{0.007} & \multicolumn{3}{|l|}{ NS } & \multicolumn{3}{|l|}{ NS } \\
\hline
\end{tabular}




\section{Narender et al.}

Soil organic carbon under Melia dubia and in without tree conditions showed significant variation in both 0-15 and 15-30 cm soil depth (Table 2). Going deeper in the soil depth it was observed that organic carbon decreased under tree and without tree conditions in both the observations taken before sowing and after harvest. Plots integrated with tree were significantly higher in organic carbon content $(0.46 \%)$ at $0-15 \mathrm{~cm}$ compared to $(0.30 \%) 15-30 \mathrm{~cm}$ after harvesting wheat varieties. A decrease in open conditions from 0.35 to $0.34 \%$ and 0.23 to $0.21 \%$ after harvest among both depths (0-15 cm and 15-30) was found respectively. Soil organic carbon under Melia plantation increased significantly at both depths compared to the initial status of organic carbon. Lack of lignified cells in agricultural residues might be the reason for lower organic carbon in the study plots lacking trees. Another reason that has attributed is soil being exposed to the sun at its fullest.

Organic carbon content in the soil is a robust factor of soil quality, specifically in semiarid areas for the determination of agronomic production (Sharma et al., 2014). Gill and Burman (2002) stated that the addition of litter, annual fine root biomass and root exudates, as well as decreased oxidation of organic matter under tree shade, could all contribute to amelioration of soil. Arya and Toky (2017) in their study on poplar based agri-silviculture system found them extremely useful as tree-based cropping system add a large amount of litter hence, ultimately increase amount of organic matter content in the soil. Tropical agroforests have been found to play a significant part in storing organic carbon content in the soil. The total amount of organic carbon in the soil was discovered to be 24.91 tonnes per hectare (Magar et al., 2020). Agroforestry provides an approach through which in very little time organic content could be added by selection of proper nitrogen-fixing tree species and if they are fast-growing too (Tsufac et al., 2021). The value of EC varied significantly under different environment and soil depth before and after harvesting wheat varieties (Table 3). A decrease in EC was recorded at both the soil depths under Melia dubia plantation as compared to without tree. The electrical conductivity of soil decreased from 0.46 to $0.44 \mathrm{dSm}^{-1}$ at $0-15 \mathrm{~cm}$ soil depth and 0.38 to $0.36 \mathrm{dSm}^{-1}$ at $15-30 \mathrm{~cm}$ under tree during the data collection after harvesting. The decrease in value of EC was higher under plots with trees than in without trees at both the soil depths i.e. 0.51 to $0.50 \mathrm{dSm}^{-1}(0-15 \mathrm{~cm})$ and 0.45 to $0.43 \mathrm{dSm}^{-1}$ $(15-30 \mathrm{~cm})$. Maximum decrease $\left(0.03 \mathrm{dSm}^{-1}\right)$ in EC was found under trees at soil depth of $0-15 \mathrm{~cm}$. The electrical conductivity at both soil depths decreased under Melia dubia based agroforestry system. The rate of decrease in electrical conductivity was comparatively low in without tree. Similar observations regarding pattern of electrical conductivity were reported by Patel et al. (2010). Agroforestry is capable of ameliorating the soils affected by salt and low fertility. It reduces the burden of productive soils for the fulfillment of food requirements of a growing population and various conservational issues (Sharma et al., 2014). The absence of proper quantitative knowledge about the performance of various field crops and resource competition with tree is a chief hindrance in the adoption of agroforestry system for farmers (Artru et al., 2017).

The data presented in table 3 depicts that soil nitrogen under Melia plantation soil nitrogen increased significantly. The increase in soil nitrogen was more in the upper layer of soil under tree plantation i.e. from 130.43 to $131.38(\mathrm{~kg} / \mathrm{ha})$ at $0-15 \mathrm{~cm}$ and 126.88 to $127.25(\mathrm{~kg} / \mathrm{ha})$ at $15-30 \mathrm{~cm}$. The soil available nitrogen was observed to have less quantity in without tree conditions as compared to under tree conditions in both soil depths. Table 2 and 3 depicts data for available macronutrients in the soil advocates for their increased values under Melia dubia plantation from their initial values. There was an improvement in the available nitrogen content at harvesting time probably because of the rise of humus in soil after decomposition of litter fall of Melia tree. Githae et al. (2011) in an Acaciabased agri-silviculture system witnessed similar results in their study. They reported that the nitrogen content of soil under agri-silviculture system increased because of litter fall accumulation by Acacia. Various researchers such as Tiwari and Baghel (2014) and Bhardwaj et al. (2017) noted the positive behavior of agroforestry in increasing the nutrient status and enhancing the fertility of soil in their research. The rise in available nitrogen under agri-silviculture system is because of extra moisture in the shade, combined with a more moderate temperature, resulting in breakdown of litter, mineralization and nitrogen gain at a faster rate 
Potential of Melia dubia agroforestry system in soil improvement

Table 4: Soil phosphorus and potassium content at different depth before sowing and after harvesting of wheat varieties in control (field without trees) and under tree conditions

\begin{tabular}{|c|c|c|c|c|c|c|c|c|c|c|c|c|}
\hline \multirow{3}{*}{ Soil Depth (cm) } & \multicolumn{6}{|c|}{ Available phosphorus (kg/ha) } & \multicolumn{6}{|c|}{ Available potassium (kg/ha) } \\
\hline & \multicolumn{3}{|c|}{ Before sowing } & \multicolumn{3}{|c|}{ After harvest } & \multicolumn{3}{|c|}{ Before sowing } & \multicolumn{3}{|c|}{ After harvest } \\
\hline & $\begin{array}{l}\text { Under } \\
\text { Tree }\end{array}$ & $\begin{array}{l}\text { Without } \\
\text { Tree }\end{array}$ & Mean & $\begin{array}{l}\text { Under } \\
\text { Tree }\end{array}$ & $\begin{array}{l}\text { Without } \\
\text { Tree }\end{array}$ & Mean & $\begin{array}{l}\text { Under } \\
\text { Tree }\end{array}$ & $\begin{array}{l}\text { Without } \\
\text { Tree }\end{array}$ & Mean & $\begin{array}{l}\text { Under } \\
\text { Tree }\end{array}$ & $\begin{array}{l}\text { Without } \\
\text { Tree }\end{array}$ & Mean \\
\hline 0-15 & 15.33 & 13.63 & 14.48 & 16.00 & 13.51 & 14.75 & 297.38 & 248.63 & 273.00 & 301.10 & 251.38 & 276.24 \\
\hline 15-30 & 8.43 & 7.53 & 7.98 & 8.60 & 7.43 & 8.01 & 288.93 & 244.20 & 266.56 & 295.05 & 247.95 & 271.50 \\
\hline Mean & 11.88 & 10.58 & & 12.30 & 10.47 & & 293.15 & 246.41 & & 298.08 & 249.66 & \\
\hline \multicolumn{13}{|l|}{ C. D. at 5\% } \\
\hline Depth & 0.119 & & & 0.055 & & & 2.777 & & & 2.962 & & \\
\hline Environment & 0.119 & & & 0.055 & & & 2.777 & & & 2.962 & & \\
\hline $\mathbf{D} \times \mathbf{E}$ & 0.168 & & & 0.078 & & & NS & & & $\mathrm{NS}$ & & \\
\hline
\end{tabular}

Table 5: Soil moisture status at different soil depth and distance form tree row for first and second irrigation in sole and under tree condition.

\begin{tabular}{|c|c|c|c|c|c|c|c|c|c|c|c|c|c|c|c|c|c|c|}
\hline \multicolumn{19}{|c|}{ First irrigation } \\
\hline \multirow{3}{*}{$\begin{array}{l}\text { Soil Depth } \\
\text { (cm) }\end{array}$} & \multicolumn{6}{|c|}{ Before irrigation } & \multicolumn{6}{|c|}{ After 7 days of irrigation } & \multicolumn{6}{|c|}{ After 14 days of irrigation } \\
\hline & \multicolumn{2}{|l|}{$0.5 \mathrm{~m}$} & \multicolumn{2}{|l|}{$1 \mathrm{~m}$} & \multicolumn{2}{|l|}{$1.5 \mathrm{~m}$} & \multicolumn{2}{|l|}{$0.5 \mathrm{~m}$} & \multicolumn{2}{|l|}{$1 \mathrm{~m}$} & \multicolumn{2}{|l|}{$1.5 \mathrm{~m}$} & \multicolumn{2}{|l|}{$0.5 \mathrm{~m}$} & \multicolumn{2}{|l|}{$1 \mathrm{~m}$} & \multicolumn{2}{|l|}{$1.5 \mathrm{~m}$} \\
\hline & UT & WT & UT & WT & UT & WT & UT & WT & UT & WT & UT & WT & UT & WT & UT & WT & UT & WT \\
\hline $0-15$ & 11.90 & 8.91 & 11.71 & 8.61 & 11.62 & 8.58 & 16.00 & 10.60 & 15.73 & 10.20 & 15.69 & 10.11 & 14.30 & 9.80 & 14.10 & 9.30 & 14.06 & 9.21 \\
\hline 15-30 & 12.07 & 9.90 & 11.76 & 9.10 & 11.72 & 9.06 & 18.40 & 16.20 & 18.00 & 15.70 & 17.92 & 15.59 & 15.20 & 12.10 & 14.95 & 11.83 & 14.90 & 11.76 \\
\hline CD at $5 \%$ & \multicolumn{6}{|c|}{$\begin{array}{l}\text { Distance }=0.22 \\
\text { Depth }=1.8 \\
\text { Distance } \times \text { Depth }=\text { NS }\end{array}$} & \multicolumn{6}{|c|}{$\begin{array}{l}\text { Distance }=0.31 ; \\
\text { Depth }=0.26 ; \\
\text { Distance } \times \text { Depth }=\text { NS }\end{array}$} & \multicolumn{6}{|c|}{$\begin{array}{l}\text { Distance }=\mathrm{NS} ; \\
\text { Depth }=0.27 ; \\
\text { Distance } \times \text { Depth }=\mathrm{NS}\end{array}$} \\
\hline \multicolumn{19}{|c|}{ Second irrigation } \\
\hline \multirow{3}{*}{$\begin{array}{l}\text { Soil Depth } \\
\text { (cm) }\end{array}$} & \multicolumn{6}{|c|}{ Before irrigation } & \multicolumn{6}{|c|}{ After 7 days of irrigation } & \multicolumn{6}{|c|}{ After 14 days of irrigation } \\
\hline & \multicolumn{2}{|l|}{$0.5 \mathrm{~m}$} & \multicolumn{2}{|l|}{$1 \mathrm{~m}$} & \multicolumn{2}{|l|}{$1.5 \mathrm{~m}$} & \multicolumn{2}{|l|}{$0.5 \mathrm{~m}$} & \multicolumn{2}{|l|}{$1 \mathrm{~m}$} & \multicolumn{2}{|l|}{$1.5 \mathrm{~m}$} & \multicolumn{2}{|l|}{$0.5 \mathrm{~m}$} & \multicolumn{2}{|l|}{$1 \mathrm{~m}$} & \multicolumn{2}{|l|}{$1.5 \mathrm{~m}$} \\
\hline & UT & WT & UT & WT & UT & WT & UT & WT & UT & WT & $\mathbf{U T}$ & WT & UT & WT & UT & WT & UT & WT \\
\hline $0-15$ & 11.60 & 9.27 & 11.20 & 8.80 & 11.11 & 8.77 & 18.10 & 17.30 & 17.80 & 17.20 & 17.68 & 17.02 & 10.70 & 9.20 & 10.43 & 8.92 & 10.37 & 8.81 \\
\hline 15-30 & 11.91 & 10.83 & 11.04 & 10.60 & 11.30 & 10.38 & 19.40 & 18.20 & 19.10 & 17.90 & 19.02 & 17.67 & 11.10 & 9.80 & 10.97 & 9.45 & 10.93 & 10.37 \\
\hline CD at $5 \%$ & \multicolumn{6}{|c|}{$\begin{array}{l}\text { Distance }=0.21 \\
\text { Depth }=0.17 \\
\text { Distance } \times \text { Depth }=\mathrm{NS}\end{array}$} & \multicolumn{6}{|c|}{$\begin{array}{l}\text { Distance }=\mathrm{NS} \\
\text { Depth }=0.30 \\
\text { Distance } \times \text { Depth }=\mathrm{NS}\end{array}$} & $\begin{array}{l}\text { Distan } \\
\text { Depth } \\
\text { Distan }\end{array}$ & $\begin{array}{l}\mathrm{e}=\mathrm{NS} \\
0.28 \\
\mathrm{e} \times \mathrm{De}\end{array}$ & th $=$ NS & & & \\
\hline
\end{tabular}




\section{Narender et al.}

compared to full sunlight conditions (Antonio and Gama-Rodrigues, 2011). The cycling of nutrients in agroforestry system is one of the major developments that support organic matter production (Toky et al., 2018).

The available phosphorous in soil increased significantly under trees at both the soil depths (Table 4). The available phosphorus content also increased significantly over its initial values under trees. After harvesting wheat varieties the maximum available phosphorous $(16.0 \mathrm{~kg} / \mathrm{ha})$ was observed in $0-15 \mathrm{~cm}$ soil depth under trees however, available phosphorous $(7.43 \mathrm{~kg} / \mathrm{ha})$ obtained was less at $15-30 \mathrm{~cm}$ depth in open conditions. A similar trend was exhibited by phosphorus as of nitrogen depicted in (Table 4). Compared to the initial values phosphorus content of soil was observed to be increased after harvest. The increase in phosphorus content of soil was recorded more at $0-15 \mathrm{~cm}$ depth under tree conditions compared to the deeper depth of soil. Sarkar et al.(2020) stated that agroforestry recycle plant nutrients in a better way through deep root system and more litter-fall, over conventional agriculture system. Hence, agroforestry system development could be taken over crop production as stable and revival option for enhancing the sustainability of soil. Agroforestry is very promising in decontaminating the polluted soil. There are some potential agroforestry suitable tree species, which are found to be promising candidates for the phytoremediation of pollution (Sade, 2020). Available potassium in soil showed similar results as of nitrogen and phosphorus (Table 4). Highest value for available soil potassium was noted under Melia dubia trees $\left(301.10 \mathrm{~kg} \mathrm{ha}^{-1}\right)$ at a depth of $0-15 \mathrm{~cm}$ while the lowest $\left(247.95 \mathrm{~kg} \mathrm{ha}^{-1}\right)$ at a depth of $15-30 \mathrm{~cm}$ in without tree condition. An increase in potassium was observed after harvest when compared to initial values in both environments. Bisht et al. (2017) in their study suggested poplar and wheat intercropping suitable for soil physical and chemical properties. In intercropping of poplar and wheat, variety DBW711 was recorded with the highest available potassium i.e, $219.63 \mathrm{~kg} / \mathrm{ha}$ under trees. Investigators strongly recommended amalgamation of agroforestry tree species and annual crops instead of sole crop in order to enrich soil nutrients. Investigators studying various soil properties in
Terai region of North India revealed that poplar and Leucaena trees grown at $3.0 \times 1.0 \mathrm{~m}^{2}$ spacing showed results of amelioration (Sarvade et al., 2014). Agroforestry has immense possibilities for greater agricultural production, sequestration of carbon, checking soil erosion, runoff control, proper cycling of water and boosted nutrient content in the soil. As agroforestry research started developing, investigators see this approach of tackling environmental issues as a sustainable and profitable way. (Brown et al., 2018).

In open and under tree (both) conditions the moisture content in the soil increased while going deeper in the soil profile but it decreased with the increasing distance from tree line (Table 5). The maximum loss in moisture content was observed in open condition because of evapo-transpiration. The results showed that the soil depth, aspect, and distance all had a major impact on moisture content. According to the data depicted (Table 5) maximum moisture content in the soil was obtained at a depth of $15-30 \mathrm{~cm}$ of soil depth i.e, (12.1\%) under tree conditions at $0.5 \mathrm{~m}$ distance from the tree row prior to any irrigation. After irrigation also same pattern of increasing moisture content with an increase in soil depth was observed. An increasing trend of moisture content was observed while going deeper into soil profile in both the conditions of crop environment. While a decreasing pattern was recorded while moving away from tree row $(0.5$, 1.0 and $1.5 \mathrm{~m}$ ). There is more change in moisture per cent from 0.5 to $1.0 \mathrm{~m}$ than from $1.0 \mathrm{~m}$ to 1.5 $\mathrm{m}$. The minimum soil moisture per cent is found at $1.5 \mathrm{~m}$ away from tree. This might be due to maximum interaction of tress spaced at $3 \mathrm{~m} \times 3 \mathrm{~m}$. In under tree, more moisture per cent is recorded because the phenological behavior of Melia dubia being deciduous in nature helps in conservation of moisture in soil probably due to presence of litter as mulch restricting loss of moisture through evaporation and also in Rabi season Melia growth is restricted because in enters into dormancy and intake less amount of water for transpiration. Carvalho et al. (2020) concluded that shaded agroforestry coffee systems improve microclimate conditions compared with un-shaded coffee systems. Sto"cker et al. (2020) found that agrisilviculture system encouraged positive alterations in soil physical traits and resulted in consistent enhancement of soil quality. Researchers suggested 
diversified root systems of tree and accumulation of crop residues for the speedy enhancement of quality of soil. Agroforestry improves soil productivity apart from providing an assurance to the farmers against any uncertainty Arya and Toky (2017).

\section{Conclusion}

The present study indicates that Melia dubia trees grown in semi-arid environment of Haryana in an agroforestry system have positive effects on soil health. EC and $\mathrm{pH}$ were found to be decreased under Melia dubia when noted after the harvesting of the wheat varieties. The nutrients and organic carbon content increased in the intercropped system. Moisture content was higher under trees compared to open conditions and this factor contributed to overall changes showing improvement of soil fertility. Overall this very intercropping system could be suggested for its

\section{References}

Antonio, C. and Gama, R. 2011. Soil organic matter, nutrient cycling and biological dinitrogen fixation in agroforestry systems. Agroforestry Systems, 81: 191-193.

Artru, S., Garré, S., Dupraz, C., Hiel, M. P., Blitzfrayret, C. and Lassois, L. 2017. Impact of spatiotemporal shade dynamics on wheat growth and yield, perspectives for temperate agroforestry. Europian Journal of Agronomy, 82: $60-70$.

Arya, S. and Toky, O. P. 2017. Biomass production in poplar agroforestry systems in Haryana of North Western India. Indian Journal of Ecology, 44(6):785-787.

Arya, S., Toky, O. P. and Singh, K. 2018. Mitigation of climate changes through agroforestry for sustainable agriculture in India. Journal of Agrometeorology, 20:172-177.

Bhardwaj, K. K., Dhillon, R. S., Kumari, S., Johar, V., Dalal, V. and Chavan, S. B. 2017. Effect of Eucalyptus Bund Plantation on Yield of Agricultural Crops and Soil Properties in Semi-Arid Region of India. International Journal of Current Microbiology and Applied Science, 6 (10):2059-2065.

Bhardwaj, S., Khanna, D. R., Ruhela, M., Bhutiani, R., Bhardwaj, R. and Ahamad, F. 2020. Assessment of the soil quality of Haridwar Uttarakhand India: A comparative study. Environment Conservation Journal, 21 (3): 155164.

Bisht, N., Sah, V. K., Satyawali, K. and Tiwari, S. 2017. Comparison of wheat yield and soil properties under open number of benefits such as recycling through litterfall, improvement in soil fertility and environmental benefits. The study revealed the potential of Melia dubia based agroforestry system to improve the fertility of soil. Hence, it is commended that cultivators must initiate agroforestry practices integrating Melia dubia trees on their farms so as to boost the fertility of the soil and for a sustainable environment.

\section{Acknowledgements}

We are thankful to the Chaudhary Charan Singh Haryana Agricultural University, Hisar for providing research facilities. Dr. K. K. Bhardwaj Department of Soil Science, CCSHAU provided the equipments and laboratory facilities. Further, we are thankful to Sh. Jitender Singh a progressive farmer of Gillan khera for letting the research to be conducted on his farm.

and poplar based agroforestry system. Journal of Applied and Natural Science, 9 (3): 1540-1543.

Brown, S. E., Miller, D. C., Ordonez, P. J. and Baylis, K. 2018. Evidence for the impacts of agroforestry on agricultural productivity, ecosystem services and human well-being in high-income countries: a systematic map protocol. Environmental Evidence, 7: 24.

Cardinael, R., Mao, Z., Chenu, C. and Hinsinger, P. 2020. Belowground functioning of agroforestry systems: recent advances and perspectives. Plant Soil, 453: 1-13.

Carvalho, A. F., Filho, E.I. F., Daher, M., G.L.C., Cardoso, I.M., Fernandes, R.B.A. and Schaefer, C.E.G.R. 2020. Microclimate and soil and water loss in shaded and unshaded agroforestry coffee systems. Agroforest System, https://doi.org/10.1007/s10457-020-00567-6

Gill, A. S. and Burman, D. 2002. Production management of field crops in agroforestry systems. In: Recent Advances in Agronomy. (Singh G, Kolar JS and Sekhon HS Eds.) New Delhi. Indian Society of Agronomy, pp. 523-542.

Githae, E. W., Gachene, C. K. K. and Njoka, J. T. 2011. Soil physicochemical properties under Acacia senegal varieties in the dryland areas of Kenya. African Journal of Plant Science, 5:475-482.

Jackson, M. L. 1973. Soil chemical analysis. Prentice Hall of India Pvt. Ltd. New Delhi.

Jemal, O., Callo-Concha, D. and Van, N. M. 2018. Local Agroforestry Practices for Food and Nutrition Security of 


\section{Narender et al.}

Smallholder Farm Households in Southwestern Ethiopia. Sustainability, 10: 2722 .

Kmoch, L., Pagella, T., Palm, M. and Sinclair, F. 2018. Using Local Agroecological Knowledge in Climate Change Adaptation: A Study of Tree-Based Options in Northern Morocco. Sustainability, 10: 3719.

Liu, W., Yao, S., Wang, J. and Liu, M. 2019. Trends and Features of Agroforestry Research Based on Bibliometric Analysis. Sustainability, 11: 3473.

Magar, L. K., Kafle, G. and Aryal, P. 2020. Assessment of Soil Organic Carbon in Tropical Agroforests in the Churiya Range of Makawanpur, Nepal. International Journal of Forestry Research, Article ID 8816433, 5 pages.

Olsen, S. R., Cole, C. V., Watanabe, F. S. and Dean, L. A. 1954. Estimation of available phosphorous in soils by extraction with sodium bicarbonate. Circular $\boldsymbol{U S}$ Department of Agriculture, 939.

Panse, V. G. and Sukhatme P. V. 1985. Stastical methods for Agricultural workers. 4th edn. ICAR, New Delhi.

Patel, J. M., Jaimini, S. N. and Patel, S. B. 2010. Physicochemical properties of soil under different tree species, Indian Journal of Forestry, 33 (4): 565-568.

Prasadini, P. and Sreemannarayana, B. 2007. Impact of agroforestry systems on nutritional status and biological activity on rainfed red sandy loam soils. Indian Forester, 133(11): 1519-1525.

Rosenstock, T. S., Tully, K. L., Arias-Navarro, C., Neufeldt, H., Butterbach-Bahl, K. and Verchot, L. V. 2014 Agroforestry with N2-fixing trees: sustainable development's friend or foe? Current Opinion in Environmental Sustainability, 6: 15-21.

Sade, A. G. 2020. Role of Agroforestry in Phytoremediation of Contaminated Soils: Review. International Journal of Current Research and Academic Review, 8(9): 29-37.

Sarkar, S., Das, D. K. and Singh, A. 2020. Soil micronutrients status of different agroforestry systems in north Bihar. Journal of Pharmacognosy and Phytochemistry, 9(5):355-358
Sarvade, S., Mishra, H. S., Kaushal, R., Chaturvedi, S. and Tewari, S. 2014. Wheat (Triticum aestivum L.) Yield and Soil Properties as Influenced by Different Agri-silviculture Systems of Terai Region, Northern India. International Journal of Bio-resource and Stress Management, 5(3): $350-355$

Sharma, D. K., Chaudhari, S. K. and Singh, A. 2014. In Salt Affected Soils Agroforestry is a promising option. Indian Farming, 63(11): 19-22.

Stocker, C. M., Bamberg, A. L., Stumpf, L., Monteiro, A. B., Cardoso, J. H. and Lima, A. C. R. 2020. Short-term soil physical quality improvements promoted by an agroforestry system. Agroforest Syst, https://doi.org/10.1007/s10457-020-00524-3.

Subbiah, B. V. and Asija, G. L. 1956. A rapid procedure for the estimation of available nitrogen in soils. Current Science, 25(8): 259-260.

Tiwari, R. and Baghel, B. S. 2014. Effect of intercropping on plant and soil of Dashehari mango orchard under low productive environments. Asian Journal of Horticulture, $9(2): 439-42$

Toky, O. P., Arya, S. and Malik, K. 2018. Effect of environment on nutrient cycling in poplar (Poplar deltoides) agroforestry systems in Haryana. Journal of Agrometeorology, 20: 282-286.

Tripathi, O. P., Pandey, H. N. and Tripathi, R. S. 2009. Litter production, decomposition and physico-chemical properties of soil in 3 developed agroforestry systems in Megahalaya, North East India. African Journal of Plant Science, 3(8): 160-167.

Tsufac, A. R., Awazi, N. P. and Yerima, B. P. K. 2021. Characterization of agroforestry systems and their effectiveness in soil fertility enhancement in the south-west region of Cameroon. Current Research in Environmental Sustainability, 3: 100024.

Walkley, A. J. and Black, C. A. 1934. Estimation of soil organic carbon by the chronic acid titration method. Soil Science, 37: 29-38. 